\title{
PERSEPSI ALUMNI TERHADAP PELATIHAN MANAJEMEN KESEJAHTERAAN SOSIAL DI BBPPKS BANDUNG
}

\author{
Dewi Nur Rohmat ${ }^{1}$, Jajat S. Ardiwinata ${ }^{2}$, Nike Kamarubiani ${ }^{3}$ \\ 1,2,3. Departemen Pendidikan Luar Sekolah Fakultas Ilmu Pendidikan \\ Universitas Pendidikan Indonesia J1. Dr. Setiabudhi No. 229 Bandung \\ Email: dewi_nur2294@yahoo.com
}

\begin{abstract}
Abstrak
Penelitian ini berlatar belakang atas banyaknya permasalahan sosial yang terjadi pada anak, Lembaga Kesejahteraan Sosial Anak (LKSA) yang mempunyai tugas dan fungsi sebagai penyelenggara pengasuhan anak, maka diharapkan dapat meningkatkan kompetensi pengelola LKSA (Lembaga Kesejahteraan Sosial Anak) agar dapat mengatasi permasalahan yang terjadi dalam keluarga mengenai pengasuhan anak dan dapat mengurangi permasalahan sosial yang saat ini sedang marak terjadi kepada anak. Tujuan penelitian ini adalah sebagai berikut: 1) Untuk memperoleh gambaran pelaksanaan Pelatihan Manajemen Kesejahteraan Sosial berdasarkan aspek: materi pelatihan, metode pembelajaran, pelatih, peserta pelatihan, sarana dan prasarana pelatihan, dan evaluasi pelatihan, 2) Untuk mengetahui persepsi alumni terhadap Pelatihan Manajemen Kesejahteraan Sosial di BBPPKS Bandung berdasarkan jenis kelamin, usia, latar belakang pendidikan, jabatan dan asal provinsi wilayah kerja. Teori pendukung dalam penelitian ini adalah konsep persepsi dan konsep pelatihan. Metode yang digunakan adalah metode deskriptif dengan pendekatan kuantitatif. Teknik pengumpulan data yang digunakan adalah angket dan dokumentasi. Populasi dalam penelitian ini adalah alumni peserta pelatihan manajemen kesejahteraan sosial di BBPPKS Bandung yang berjumlah 30 orang. Hasil penelitian menentukan bahwa Persepsi alumni terhadap Pelatihan Manajemen Kesejahteraan Sosial di BBPPKS Bandung berdasarkan aspek materi pelatihan, metode pembelajaran, pelatih, peserta pelatihan, sarana dan prasarana pelatihan, dan evaluasi pelatihan masuk dalam kategori "tinggi" yang menunjukkan bahwa Pelatihan Manajemen Kesejahteraan Sosial yang telah diselenggarakan oleh BBPPKS Bandung sudah cukup baik karena ada pada kategori "tinggi". Berdasarkan hasil presentase skor yang di peroleh, jenis kelamin laki-laki, usia antara 19-26 tahun, latar belakang pendidikan Diploma, jabatan pengurus dan alumni yang berasal dari Provinsi Jawa Barat memiliki hasil presentase skor yang paling tinggi.
\end{abstract}

Kata Kunci : Persepsi alumni terhadap pelatihan, Pelatihan, Manajemen Kesejahteraan Sosial.

\section{Pendahuluan}

Pada era globalisasi ini, kebutuhan serta tantangan untuk bertahan hidup menjadi semakin berat. Kebutuhan yang semakin bertambah banyak berbanding terbalik dengan kemampuan manusia untuk memenuhi kebutuhannya, karena Sumber Daya Alam dan Sumber Daya Manusia yang terbatas. Hal ini tidak hanya berdampak pada orang dewasa, tetapi usia kanak-kanak pun mendapatkan dampak sosial yang menyebabkan permasalahan sosial yang terjadi pada saat ini.
Lembaga Kesejahteraan Sosial Anak merupakan organisasi sosial yang melaksanakan penyelenggaraan kesejahteraan sosial yang berfokus pada kesejahteraan sosial anak. Dalam Peraturan Menteri Sosial No. 30 tahun 2011 tentang Standar Nasional Pengasuhan Anak untuk Lembaga Kesejahteraan Sosial Anak Pasal 1 ayat (2), "Lembaga Kesejahteraan Sosial Anak merupakan lembaga-lembaga yang dibentuk oleh Pemerintah, Pemerintah Daerah, atau

Permasalahan sosial yang terjadi pada anak sangatlah beragam sehingga Lembaga 
Kesejahteraan Sosial Anak perlu melakukan pelayanan seoptimal mungkin yang dapat mereka lakukan. Permasalahan sosial yang terjadi pada anak seperti kekerasan berupa pelecehan seksual, kekerasan fisik dan psikis masih sering terjadi. Tiga dari seratus anak Indonesia pernah mengalami kekerasan. Sejumlah 70,5\% pelaku kekerasan terhadap anak lebih banyak dilakukan oleh orang-orang yang seharusnya menjadi pelindung bagi anak itu sendiri, misalnya orang tua, kerabat dekat, tetangga, hingga guru(Menkokesra, 2013 dalam nasyiah.or.id). Hal ini sangat memprihatinkan mengingat seharusnya rumah dan sekolah menjadi tempat yang nyaman bagi anak, tetapi justru saat ini rumah dan sekolah menjadi salah satu tempat terjadinya permasalahan sosial bagi anak.

Pelatihan Manajemen Kesejahteraan Sosial Bagi Pengelola LKSA yang dilaksanakan oleh Balai Besar Pendidikan dan Pelatihan Kesejahteraan Sosial (BPPKS) Bandung merupakan Pelatihan yang ditujukan bagi pengelola agar dapat mengelola Lembaga Kesejahteraan Sosial Anak dengan lebih baik. Pelatihan ini dilaksanakan pada tahun 2014 sebagai pelatihan reguler yaitu pelatihan yang dilaksanakan berdasarkan kebutuhan dengan jumlah peserta 30 orang (1 Angkatan) berasal dari 6 (enam) provinsi wilayah kerja BBPPKS Regional Bandung yaitu Provinsi Jawa Barat, Provinsi Kalimantan Barat, Provinsi Kepulauan Bangka Belitung, Provinsi Lampung, Provinsi DKI Jakarta dan Provinsi Banten yang menjadi pengurus panti sosial anak, organisasi sosial, yayasan maupun LSM yang bergerak di bidang kesejahteraan sosial anak.
Berdasarkan pada uraian yang ada maka peneliti tertarik ingin melakukan penelitian lebih lanjut untuk mengetahui "Persepsi Alumni terhadap Pelatihan Manajemen Kesejahteraan Sosial di BBPPKS Bandung”. Penelitian ini dilakukan terhadap alumni peserta Pelatihan Manajemen Kesejahteraan Sosial bagi Pengelola LKSA yang diselenggarakan oleh Balai Besar Pendikan dan Pelatihan Kesejahteraan Bandung (BPPKS) Bandung.

\section{Kajian Literatur}

Kajian teori yang relevan dengan penelitianiniyaitu:DavidoffdanRogers dalam (Walgito, 2010, hlm. 100) mengemukakan bahwa "persepsi dapat dikemukakan karena perasaan, kemampuan berfikir, pengalamanpengalaman individu tidak sama, maka dalam mempersepsi sesuatu stimulus, hasil persepsi mungkin akan berbeda antara individu satu dengan individu lain. Persepsi itu bersifat individual". Kemudian Sarwono (2009, hlm. 24) mengungkapkan bahwa "dalam psikologi, persepsi secara umum merupakan proses perolehan, penafsiran, pemilihan, dan pengaturan informasi indrawi”. Sedangkan Walgito (2010, hlm. 99) menyatakan bahwa persepsi merupakan, "suatu proses yang didahului oleh proses pengideraan, yaitu merupakan proses diterimanya stimulus oleh individu melalui alat indra atau juga disebut proses sensoris. Namun proses itu tidak berhenti begitu saja, melainkan stimulus tersebut diteruskan dan proses selanjutnya merupakan proses persepsi”.

Pengertian Pelatihan menurut Sudjana (2007, hlm. 4) mengemukakan bahwa, "Pelatihan adalah upaya pembelajaran, yang 
diselenggarakan oleh organisasi (instansi Pemerintah, lembaga swadaya masyarakat, perusahaan, dan lain sebagainya) untuk memenuhi kebutuhan atau untuk mencapai tujuan organisasi”. Sedangkan menurut Robinson (dalam Marzuki, 2010, hlm. 174) menyatakan "training adalah pengajaran atau pemberian pengalaman kepada seseorang untuk mengembangkan tingkah laku (pengetahuan, skill, sikap) agar mencapai sesuatu yang diinginkan".

Donald Kirkpatrick (1950) dalam bdkjakarta.kemenag.go.id mengemukakan ke-4 tahap proses yang dikenal dengan the four level evaluation, merupakan serangkaian proses yang dinamis, yaitu level 1 (Reaksi), level 2 (Pembelajaran), level 3 (perilaku), dan level 4 (hasil). Evaluasi reaksi ini sama halnya dengan mengukur tingkat kepuasan peserta pelatihan. Komponen-komponen yang termasuk dalam level reaksi ini yang merupakan acuan untuk dijadikan ukuran. Komponen-komponen tersebut berikut indikator-indikatornya adalah: a. Instruktur/ Pelatih (Dalam komponen ini terdapat hal yang lebih spesifik lagi yang dapat diukur yang disebut juga dengan indikator. Indikatorindikatornya adalah kesesuaian keahlian pelatih dengan bidang materi, kemampuan komunikasi dan ketermapilan pelatih dalam mengikut sertakan peserta pelatihan untuk berpartisipasi), b. Fasilitas Pelatihan (Dalam komponen ini, yang termasuk dalam indikator-indikatornya adalah ruang kelas, pengaturan suhu di dalam ruangan dan bahan dan alat yang digunakan), c. Jadwal Pelatihan (Yang termasuk indikator-indikator dalam komponen ini adalah ketepatan waktu dan kesesuaian waktu dengan peserta pelatihan, atasan para peserta dan kondisi belajar), d. Media Pelatihan (Dalam komponen ini, indikator-indikatornya adalah kesesuaian media dengan bidang materi yang akan diajarkan yang mampu berkomunikasi dengan peserta dan menyokong instruktur/ pelatihan dalam memberikan materi pelatihan), e. Materi Pelatihan (Yang termasuk indikator dalam komponen ini adalah kesesuaian materi dengan tujuan pelatihan, kesesuaian materi dengan topik pelatihan yang diselenggarakan), Konsumsi selama pelatihan berlangsung (Yang termasuk indikator di dalamnya adalah jumlah dan kualitas dari makanan tersebut), f. Pemberian latihan atau tugas (Indikatornya adalah peserta diberikan soal), g. Studi kasus (Indikatornya adalah memberikan kasus kepada peserta untuk dipecahkan), h. Handouts (Dalam komponen ini indikatornya adalah berapa jumlah handouts yang diperoleh, apakah membantu atau tidak).

\section{Metode Penelitian}

Metode yang digunakan adalah metode deskriptif dengan pendekatan kuantitatif. Teknik pengumpulan data yang digunakan adalah angket dan dokumentasi. Penelitian ini menggunakan metode ex post facto karena meneliti sesuatu yang telah terjadi. Seperti yang diungkapkan Sukardi (dalam Deni Darmawan, 2014, hlm. 4041) "penelitian ex post facto merupakan penelitian di mana variabel-variabel bebas telah terjadi ketika peneliti mulai dengan pengamatan variabel terikat dalam suatu penelitian."

Populasi dalam penelitian ini adalah alumni peserta pelatihan manajemen 
Kesejahteraan Sosial bagi pengelola LKSA di BBPPKS Bandung yang berjumlah 30 (tiga puluh) orang yang berasal dari 6 provinsi wilayah kerja BBPPKS Bandung yaitu Jawa Barat, DKI Jakarta, Banten, Lampung, Bangka Belitung dan Kalimantan Barat. Sampel dalam penelitian ini merupakan sampel total, yaitu alumni peserta pelatihan BBPPKS Bandung yang berjumlah 30 (tiga puluh) orang.

\section{Hasil Penelitian dan Pembahasan}

Interpretasi hasil penelitian mengacu kepada tujuan penelitian yaitu untuk mendeskripsikan tentang: (1) Gambaran Pelaksanaan Pelatihan Manajemen Kesejahteraan Sosial, (2) Persepsi Alumni terhadap Pelatihan Manajemen Kesejahteraan Sosial.

\section{Gambaran Pelaksanaan Pelatihan Manajemen Kesejahteraan Sosial}

Gambaran pelaksanaan Pelatihan Manajemen Kesejahteraan Sosial berdasarkan aspek materi pelatihan, metode pembelajaran, pelatih, peserta pelatihan, sarana dan prasarana pelatihan, evaluasi pelatihan adalah sebagai berikut:

Dalam materi pelatihan, urutan materi yang diberikan saat pelatihan manajemen kesejahteraan sosial adalah sebagai berikut: materi Kebijakan Kesejahteraan Sosial Anak yang berlangsung selama 2 jam latihan, ProgramPerlindunganAnakyangberlangsung selama 2 jam latihan, Pengenalan Pendekatan Berbasis Sistem yang berlangsung selama 11 jam latihan, Keberlanjutan Pengasuhan yang berlangsung 16 jam latihan, Perangkat untuk melakukan Pemrograman yang berlangsung selama 11 jam latihan, Energiser yang berlangsung selama 4 jam latihan, Praktik Belajar Lapangan yang berlangsung selama 28 jam latihan, materi lainnya (pengarahan program, pembukaan, dan sebagainya) yang berlangsung selama 6 jam. Jadi total jam latihan pada materi pelatihan berlangsung selama 80 jam.

Pada materi Kebijakan Kesejahteraan Sosial Anak dan Program Perlindungan Anak hanya berlangsung selama 2 jam latihan karena hanya materi dasar dan tidak mempunyai sub pokok bahasan yang terlalu banyak. Pada materi Pengenalan Pendekatan Berbasis Sistem dan Perangkat untuk melakukan Pemrograman berlangsung 11 jam latihan, lalu materi Keberlanjutan Pengasuhan berlangsung selama 16 jam latihan, karena mempunyai sub pokok bahasan yang cukup banyak serta peserta membutuhkan waktu yang lebih lama untuk mempelajari materi yang mempunyai sub pokok bahasan yang banyak dibandingkan dengan mempelajari materi dasar. Pada materi Energiser hanya berlangsung selama 4 jam latihan karena berisi ice breaking agar peserta pelatihan tetap semangat dan fokus dalam menyerap materi yang diberikan oleh pelatih. Pada materi Praktik Belajar Lapangan merupakan jam latihan yang paling banyak dan disimpan pada jadwal terakhir, yaitu berlangsung selama 28 jam latihan karena Praktik Belajar Lapangan sangat diperlukan oleh peserta pelatihan dalam mengaplikasikan materi yang telah di dapat selama pelatihan serta dapat membantu peserta pelatihan dalam mempelajari permasalahan yang ada dalam LKSA.

Donald Kirkpatrick (1950) dalam 
bdkjakarta.kemenag.go.id mengemukakan "yang termasuk indikator dalam komponen materi pelatihan adalah kesesuaian materi dengan tujuan pelatihan, kesesuaian materi dengan topik pelatihan yang diselenggarakan". Kemudian Bambang Wahyudi (2002, hlm. 123) mengemukakan bahwa "dengan mengetahui kebutuhan akan pelatihan, sebagai hasil dari langkah yang pertama dapat ditentukan materi pelatihan yang harus diberikan".

Perumusan materi yang dibuat oleh panitia pelatihan manajemen kesejahteraan sosial BBPPKS Bandung melalui tahapan identifikasi kebutuhan, sehingga materi yang diberikan saat pelatihan manajemen kesejahteraan sosial telah sesuai dengan tujuan pelatihan dan topik pelatihan yang diselenggarakan serta urutan materi yang diberikan pada pelatihan manajemen kesejahteraan sosial dirancang dari pemberian materi dasar agar peserta pelatihan lebih mudah memahami materi yang diberikan saat pelatihan. Dalam tabel analisis deskriptif data penelitian, tanggapan responden dari 7 pernyataan mengenai materi pelatihan sebesar $73,93 \%$ termasuk dalam kategori "Tinggi". Sudjana (2007, hlm. 148) menyatakan bahwa materi pembelajaran dalam pelatihan pada dasarnya adalah "sekumpulan keterampilan, pengetahuan, sikap dan nilai-nilai tertentu untuk mencapai tujuan pelatihan." Hal tersebut menunjukkan bahwa tanggapan responden mengenai materi pelatihan cukup baik karena termasuk dalam kategori tinggi, artinya materi yang diberikan saat pelatihan manajemen kesejahteraan sosial sudah cukup baik, karena membantu peserta pelatihan dalam memahami materi pelatihan dan jika peserta pelatihan dapat memahami dengan baik materi pelatihan yang diberikan, maka tujuan pelatihan akan tercapai dengan baik.

Pada metode pembelajaran yang digunakan dalam pelatihan manajemen kesejahteraan sosial adalah metode ceramah/ tanya jawab, curah pendapat, diskusi, studi kasus dan praktik belajar lapangan. Metode Pembelajaran yang digunakan dalam pelatihan manajemen kesejahteraan sosial disesuaikan dengan materi yang diberikan saat pelatihan, agar materi yang diberikan dapat membantu peserta dalam memahami materi yang diberikan saat pelatihan. Hal ini senada dengan Bambang Wahyudi (2002, hlm. 123) yang menyatakan bahwa metode pembelajaran, "sesuai dengan materi pelatihan yang dibutuhkan, maka ditentukanlah metode/cara penyajian yang paling tepat. Penentuan atau pemilihan metode pelatihan tersebut disamping didasarkan atas materi yang akan disajikan, juga berkaitan dengan tingkatan tenaga kerja yang akan dilatih".

Dalam tabel analisis deskriptif data penelitian, tanggapan responden dari 8 pernyataan mengenai metode pembelajaran sebesar $69.38 \%$ termasuk dalam kategori "Tinggi". Hal tersebut menunjukkan bahwa tanggapan responden mengenai metode pembelajaran cukup baik karena termasuk dalam kategori tinggi, artinya metode pembelajaran yang diberikan saat pelatihan manajemen kesejahteraan sosial sudah cukup baik, karena membantu peserta pelatihan dalam memahami materi pelatihan dan jika peserta pelatihan dapat memahami dengan baik materi pelatihan yang diberikan, maka tujuan pelatihan akan tercapai dengan baik. 
Mengenai fasilitator dan narasumber (pelatih) dalam pelatihan manajemen kesejahteraan sosial adalah Pejabat Struktural Kementrian Sosial RI, Widyaiswara di lingkungan BBPPKS Regional II Bandung, dan Praktisi. Pelatih yang menyampaikan materi dalam pelatihan manajemen kesejahteraan sosial adalah pelatih yang mempunyai keahlian yang sesuai dengan bidang materi, kemampuan komunikasi dan mempunyai keterampilan dalam mengikut sertakan peserta pelatihan untuk berpartisipasi serta merupakan pelatih yang mempunyai banyak pengalaman yang dapat dibagikan kepada peserta pelatihan sehingga dapat membantu peserta pelatihan dalam memahami materi pelatihan. Hal ini senada dengan yang diungkapkan oleh Donald Kirkpatrick (1950) dalam bdkjakarta.kemenag.go.id mengemukakan "dalam komponen pelatih terdapat hal yang lebih spesifik lagi yang dapat diukur yang disebut juga dengan indikator. Indikatorindikatornya adalah kesesuaian keahlian pelatih dengan bidang materi, kemampuan komunikasi dan keterampilan pelatih dalam mengikut sertakan peserta pelatihan untuk berpartisipasi."

Dalam tabel analisis deskriptif data penelitian, tanggapan responden dari 2 pernyataan mengenai pelatih sebesar $64.17 \%$ termasuk dalam kategori "Tinggi". Hal tersebut menunjukkan bahwa tanggapan responden mengenai pelatih cukup baik karena termasuk dalam kategori tinggi, artinya keahlian pelatih sesuai dengan materi yang diberikan dan dapat membantu peserta pelatihan dalam memahami materi pelatihan dan jika peserta pelatihan dapat memahami dengan baik materi pelatihan yang diberikan, maka tujuan pelatihan akan tercapai dengan baik.

Peserta yang mengikuti Pelatihan ini berjumlah 30 orang TKSM yang berasal dari 6 (enam) provinsi wilayah kerja BBPPKS Regional II Bandung, yang terdiri Provinsi Kalimantan Barat yang berjumlah 3 orang, Provinsi Kepulauan Bangka Belitung 3 orang, Provinsi Lampung 4 orang, Provinsi Banten 6 orang, Provinsi Jawa Barat 10 orang, Provinsi DKI Jakarta 5 orang. Bambang Wahyudi (2002, hlm. 123) mengemukakan: Agar program pelatihan dapat mencapai sasaran, hendaklah para pesertanya dipilih yang benar-benar "siap latih". Artinya tenaga kerja yang diikutsertakan dalam pelatihan adalah mereka yang secara mental telah dipersiapkan untuk mengikuti program tersebut. Jumlah pesertanya pun perlu dibatasi sesuai dengan fasilitas yang mungkin disediakan, sehingga efektivitas program dapat tetap terjaga. Peserta yang mengikuti pelatihan manajemen kesejahteraan sosial adalah peserta yang terpilih mengikuti kegiatan pelatihan manajemen kesejahteraan sosial, penentuan peserta pelatihan dilakukan oleh BBPPKS Bandung dan pemanggilan peserta melakukan kerjasama dengan pemerintah kota atau wilayah kerja peserta pelatihan yang diundang untuk mengikuti pelatihan manajemen kesejahteraan sosial.

Dalam tabel analisis deskriptif data penelitian, tanggapan responden dari 2 pernyataan mengenai peserta pelatihan sebesar $68.75 \%$ termasuk dalam kategori "Tinggi". Hal tersebut menunjukkan bahwa tanggapan responden mengenai peserta pelatihan cukup baik karena termasuk dalam 
kategoritinggi, artinya peserta yang mengikuti pelatihan manajemen kesejahteraan sosial adalah peserta terpilih dari tempat kerjanya dan siap mengikuti pelatihan manajemen kesejahteraan sosial yang diselenggarakan oleh BBPPKS Bandung.

Sarana dan prasarana yang dapat digunakan selama Pelatihan Manajemen Kesejahteraan adalah Ruang kelas, Ruang aula, Perpustakaan, Wisma, Ruang makan, Masjid, Ruang koperasi, Laboratorium komputer dengan kelengkapannya termasuk internet, Ruang fitness dan Outbound. Sarana dan prasarana yang dapat digunakan selama pelatihan di BBPPKS Bandung mendukung keberhasilan pelatihan yang diselenggarakan. Seperti yang telah diungkapkan oleh Bambang Wahyudi (2002, hlm. 123) yang mengemukakan "semua fasilitas yang dibutuhkan untuk mendukung berlangsungnya pelatihan dan pengembangan seperti gedung/ruangan, alat tulis kantor, alat peraga, konsumsi, dukungan keuangan dan sebagainya, hendaknya dipersiapkan secara teliti. Pengadaan fasilitas ini tampaknya sangat mempengaruhi keberhasilan suatu program pelatihan."

Dalam tabel analisis deskriptif data penelitian, tanggapan responden dari 17 pernyataan mengenai sarana dan prasarana pelatihan sebesar $79.27 \%$ termasuk dalam kategori "Tinggi". Hal tersebut menunjukkan bahwa tanggapan responden mengenai sarana dan prasarana pelatihan cukup baik karena termasuk dalam kategori tinggi, artinya peserta yang mengikuti pelatihan manajemen kesejahteraan sosial cukup puas dengan sarana dan prasarana yang ada di BBPPKS Bandung dan mendukung tercapainya tujuan pelatihan manajemen kesejahteraan sosial yang diselenggarakan BBPPKS Bandung.

Evaluasi pelatihan senantiasa dilakukan pada setiap materi pelatihan dan evaluasi akhir dilakukan secara khusus melalui suatu instrument yang telah disusun. Evaluasi yang dilakukan oleh BBPPKS Bandung digunakan sebagai pengukur sejauh mana tujuan telah tercapai dan digunakan pula untuk mengambil keputusan mengenai pelatihan manajemen kesejahteraan sosial. Hal ini senada dengan yang diungkapkan oleh Cronbach dan Stufflebeam (dalam Sudjana, 2007, hlm. 210), "menambahkan bahwa evaluasi bukan hanya pengukur sejauh mana tujuan telah tercapai tetapi digunakan pula untuk pengambilan keputusan".

Dalam tabel analisis deskriptif data penelitian, tanggapan responden dari 4 pernyataan mengenai evaluasi pelatihan sebesar 78,54\% termasuk dalam kategori "Tinggi". Hal tersebut menunjukkan bahwa tanggapan responden mengenai evaluasi pelatihan cukup baik karena termasuk dalam kategori tinggi, artinya evaluasi pelatihan yang digunakan oleh BBPPKS Bandung sudah cukup baik dalam mengukur sejauh mana tujuan telah tercapai.

\section{Persepsi Alumni terhadap Pelatihan Manajemen Kesejahteraan Sosial}

Persepsi alumni terhadap Pelatihan Manajemen Kesejahteraan Sosial yang diselenggarakan oleh Balai Besar Pendidikan danPelatihanKesejahteraan Sosial(BBPPKS) Regional II Kota Bandung berdasarkan Jenis Kelamin, Usia, Latar Belakang Pendidikan, Jabatan dan Asal Provinsi Wilayah Kerja adalah sebagai berikut: Persepsi alumni 
terhadap Pelatihan Manajemen Kesejahteraan Sosial yang diselenggarakan oleh Balai Besar Pendidikan dan Pelatihan Kesejahteraan Sosial (BBPPKS) Regional II Kota Bandung berdasarkan jenis kelamin, terdapat 15 orang alumni dengan jenis kelamin laki-laki dan 15 orang jenis kelamin perempuan. Presentase skor dari tanggapan 15 responden dengan jenis kelamin laki-laki mengenai pelatihan manajemen kesejahteraan sosial yang diselenggarakan oleh BBPPKS Bandung sebesar $76.63 \%$ termasuk dalam kategori "Tinggi". Kemudian presentase skor dari tanggapan 15 responden dengan jenis kelamin perempuan mengenai pelatihan manajemen kesejahteraan sosial yang diselenggarakan oleh BBPPKS Bandung sebesar $69.42 \%$ termasuk dalam kategori "Tinggi". Berdasarkan hasil presentase skor yang di dapat, hasil presentase skor laki-laki lebih besar daripada hasil skor perempuan yaitu $76.63 \%>69.42 \%$, dapat disimpulkan bahwa pelatihan manajemen kesejahteraan sosial lebih tepat diterapkan untuk jenis kelamin laki-laki.

Persepsi alumni terhadap Pelatihan Manajemen Kesejahteraan Sosial yang diselenggarakan oleh Balai Besar Pendidikan dan Pelatihan Kesejahteraan Sosial (BBPPKS) Regional II Kota Bandung berdasarkan usia, terdapat 8 orang alumni yang berusia 19-26 tahun, 5 orang yang berusia 27-34 tahun, 4 orang yang berusia 35-42 tahun, 8 orang yang berusia 43-50 tahun, 2 orang yang berusia 51-58 tahun, dan 3 orang yang berusia 59-67 tahun. Presentase skor dari tanggapan 8 responden dengan usia 19-26 tahun mengenai pelatihan manajemen kesejahteraan sosial yang diselenggarakan oleh BBPPKS Bandung sebesar 78.75\% termasuk dalam kategori "Tinggi". Presentase skor dari tanggapan 5 responden dengan usia 27-34 tahun mengenai pelatihan manajemen kesejahteraan sosial yang diselenggarakan oleh BBPPKS Bandung sebesar 74.88\% termasuk dalam kategori "Tinggi".

Presentase skor dari tanggapan 4 responden dengan usia 35-42 tahun mengenai pelatihan manajemen kesejahteraan sosial yang diselenggarakan oleh BBPPKS Bandung sebesar $74.38 \%$ termasuk dalam kategori "Tinggi". Presentase skor dari tanggapan 8 responden dengan usia 4350 tahun mengenai pelatihan manajemen kesejahteraan sosial yang diselenggarakan oleh BBPPKS Bandung sebesar 76.64\% termasuk dalam kategori “Tinggi”. Presentase skor dari tanggapan 2 responden dengan usia 51-58 tahun mengenai pelatihan manajemen kesejahteraan sosial yang diselenggarakan oleh BBPPKS Bandung sebesar 71.56\% termasuk dalam kategori "Tinggi". Presentase skor dari tanggapan 3 responden dengan usia 59-67 tahun mengenai pelatihan manajemen kesejahteraan sosial yang diselenggarakan oleh BBPPKS Bandung sebesar $74.88 \%$ termasuk dalam kategori "Rendah". Berdasarkan hasil presentase skor yang di dapat, hasil presentase skor yang paling tinggi adalah usia 19-26 tahun yaitu $78,75 \%$ yang yang termasuk dalam kategori "Tinggi", sedangkan hasil presentase skor yang paling rendah adalah usia 59-67 tahun yaitu $44,17 \%$ yang termasuk dalam kategori "Rendah", dapat diterapkan bahwa pelatihan manajemen kesejahteraan sosial lebih tepat diterapkan untuk usia 19-26 tahun.

Persepsi alumni terhadap Pelatihan 
Manajemen Kesejahteraan Sosial yang diselenggarakan oleh Balai Besar Pendidikan dan Pelatihan Kesejahteraan Sosial (BBPPKS) Regional II Kota Bandung berdasarkan latar belakang pendidikan, terdapat 14 orang alumni yang mempunyai latar belakang pendidikan SMA/ SMK, 2 orang dengan latar belakang pendidikan Diploma, 11 orang dengan latar belakang pendidikan S1, 3 orang dengan latar belakang pendidikan S2. Presentase skor dari tanggapan 14 responden dengan latar belakang pendidikan SMA/ SMK mengenai pelatihan manajemen kesejahteraan sosial yang diselenggarakan oleh BBPPKS Bandung sebesar $69.29 \%$ termasuk dalam kategori "Tinggi". Presentase skor dari tanggapan 2 responden dengan latar belakang pendidikan Diploma mengenai pelatihan manajemen kesejahteraan sosial yang diselenggarakan oleh BBPPKS Bandung sebesar $78.13 \%$ termasuk dalam kategori "Tinggi". Presentase skor dari tanggapan 11 responden dengan latar belakang pendidikan S1 mengenai pelatihan manajemen kesejahteraan sosial yang diselenggarakan oleh BBPPKS Bandung sebesar 75.68\% termasuk dalam kategori "Tinggi”. Presentase skor dari tanggapan 3 responden dengan latar belakang pendidikan S2 mengenai pelatihan manajemen kesejahteraan sosial yang diselenggarakan oleh BBPPKS Bandung sebesar $77.29 \%$ termasuk dalam kategori "Tinggi". Berdasarkan hasil presentase skor yang di dapat, hasil presentase skor berdasarkan latar belakang pendidikan SMA/ SMK, Diploma, S1 dan S2 termasuk dalam kategori "Tinggi", dapat diartikan bahwa latar belakang pendidikan SMA/
SMK, Diploma, S1 dan S2 dapat mengikuti pelatihan kesejahteraan sosial dengan baik.

Persepsi alumni terhadap Pelatihan Manajemen Kesejahteraan Sosial yang diselenggarakan oleh Balai Besar Pendidikan dan Pelatihan Kesejahteraan Sosial (BBPPKS) Regional II Kota Bandung berdasarkan jabatan, terdapat 12 orang alumni dengan jabatan ketua, 2 orang dengan jabatan wakil ketua, 9 orang dengan jabatan sekretaris, 3 orang dengan jabatan bendahara, 1 orang dengan jabatan guru, 1 orang dengan jabatan humas, 1 orang dengan jabatan pengurus, dan 1 orang dengan jabatan pengelola. Presentase skor dari tanggapan 12 responden dengan jabatan ketua mengenai pelatihan manajemen kesejahteraan sosial yang diselenggarakan oleh BBPPKS Bandung sebesar $71.82 \%$ termasuk dalam kategori "Tinggi". Presentase skor dari tanggapan 2 responden dengan jabatan wakil ketua mengenai pelatihan manajemen kesejahteraan sosial yang diselenggarakan oleh BBPPKS Bandung sebesar 73.13\% termasuk dalam kategori "Tinggi".

Presentase skor dari tanggapan 9 responden dengan jabatan sekretaris mengenaipelatihan manajemen kesejahteraan sosial yang diselenggarakan oleh BBPPKS Bandung sebesar $73.47 \%$ termasuk dalam kategori "Tinggi". Presentase skor dari tanggapan 3 responden dengan jabatan bendahara mengenai pelatihan manajemen kesejahteraan sosial yang diselenggarakan oleh BBPPKS Bandung sebesar 80.21\% termasuk dalam kategori "Tinggi". Presentase skor dari tanggapan 1 responden dengan jabatan guru mengenai pelatihan manajemen kesejahteraan sosial yang 
diselenggarakan oleh BBPPKS Bandung sebesar $70.00 \%$ termasuk dalam kategori "Tinggi". Presentase skor dari tanggapan 1 responden dengan jabatan humas mengenai pelatihan manajemen kesejahteraan sosial yang diselenggarakan oleh BBPPKS Bandung sebesar $71.82 \%$ termasuk dalam kategori "Tinggi".

Presentase skor dari tanggapan 1 responden dengan jabatan pengurus mengenai pelatihan manajemen kesejahteraan sosial yang diselenggarakan oleh BBPPKS Bandung sebesar $97.50 \%$ termasuk dalam kategori "Sangat Tinggi". Presentase skor dari tanggapan 1 responden dengan jabatan pengelola mengenai pelatihan manajemen kesejahteraan sosial yang diselenggarakan oleh BBPPKS Bandung sebesar 31.25\% termasuk dalam kategori "Rendah". Berdasarkan hasil presentase skor yang di dapat, hasil presentase skor dengan jabatan ketua, wakil ketua, sekretaris, bendahara, guru, humas termasuk dalam kategori "Tinggi, sedangkan untuk jabatan pengurus masuk dalam kategori "Sangat Tinggi" dan jabatan pengelola masuk dalam kategori "Rendah" Berdasarkan hasil presentase skor dengan jabatan, yang paling tepat mengikuti pelatihan manajemen kesejahteraan sosial adalah jabatan pengurus.

Persepsi alumni terhadap Pelatihan Manajemen Kesejahteraan Sosial yang diselenggarakan oleh Balai Besar Pendidikan dan Pelatihan Kesejahteraan Sosial (BBPPKS) Regional II Kota Bandung berdasarkan Provinsi Wilayah Kerja, terdapat 3 orang alumni yang berasal dari Provinsi Kalimantan Barat, 2 orang berasal dari Provinsi Kep. Bangka Belitung, 2 orang dari Provinsi Lampung, 8 orang dari Provinsi Banten, 10 orang dari Provinsi Jawa Barat, 5 orang dari Provinsi Presentase skor dari tanggapan 3 responden dari Provinsi Kalimantan Barat mengenai pelatihan manajemen kesejahteraan sosial yang diselenggarakan oleh BBPPKS Bandung sebesar $72.92 \%$ termasuk dalam kategori "Tinggi". Presentase skor dari tanggapan 2 responden dari Provinsi Kep. Bangka Belitung mengenai pelatihan manajemen kesejahteraan sosial yang diselenggarakan oleh BBPPKS Bandung sebesar 73.13\% termasuk dalam kategori "Tinggi".

Presentase skor dari tanggapan 2 responden dari Provinsi Lampung mengenai pelatihan manajemen kesejahteraan sosial yang diselenggarakan oleh BBPPKS Bandung sebesar $75.31 \%$ termasuk dalam kategori "Tinggi". Presentase skor dari tanggapan 8 responden dari Provinsi Banten mengenai pelatihan manajemen kesejahteraan sosial yang diselenggarakan oleh BBPPKS Bandung sebesar $67.34 \%$ termasuk dalam kategori “Tinggi”. Presentase skor dari tanggapan 10 responden dari Provinsi Jawa Barat mengenai pelatihan manajemen kesejahteraan sosial yang diselenggarakan oleh BBPPKS Bandung sebesar $81.69 \%$ termasuk dalam kategori "Sangat Tinggi". Presentase skor dari tanggapan 5 responden dari DKI Jakarta mengenai pelatihan manajemen kesejahteraan sosial yang diselenggarakan oleh BBPPKS Bandung sebesar $63.88 \%$ termasuk dalam kategori "Tinggi".

Berdasarkan hasil presentase skor yang di dapat, hasil presentase skor dari alumni peserta pelatihan yang berasal dari Provinsi Kalimantan Barat, Kep. Bangka Belitung, 
Lampung, Banten dan DKI Jakarta termasuk dalam kategori "Tinggi” dan Provinsi Jawa Barat memperoleh hasil presentase skor tertinggi yaitu $81.69 \%$ yang masuk dalam kategori "Sangat Tinggi", dapat diartikan bahwa alumni peserta pelatihan yang berasal dari Provinsi Kalimantan Barat, Kep. Bangka Belitung, Lampung, Banten, dan DKI Jakarta dapat mengikuti pelatihan manajemen kesejahteraan sosial dengan baik, terutama untuk Provinsi Jawa Barat dengan perolehan hasil presentase skor yang paling tinggi.

\section{Simpulan Dan Saran}

\section{Simpulan}

Pelatihan Manajemen Kesejahteraan Sosial yang diadakan oleh BBPPKS Bandung sudah cukup baik dan sesuai dengan teori yang ada. Hasil penelitian menunjukkan bahwa Persepsi alumni terhadap Pelatihan Manajemen Kesejahteraan Sosial di BBPPKS Bandung berdasarkan aspek materi pelatihan, metode pembelajaran, pelatih, peserta pelatihan, sarana dan prasarana pelatihan, dan evaluasi pelatihan masuk dalam kategori "tinggi" yang menunjukkan bahwa Pelatihan Manajemen Kesejahteraan Sosial yang telah diselenggarakan oleh BBPPKS Bandung sudah cukup baik karena ada pada kategori "tinggi".

Persepsi alumni Pelatihan Manajemen Kesejahteraan Sosial berdasarkan usia, jenis kelamin, latar belakang pendidikan, jabatan dan asal provinsi wilayah kerja mempunyai hasil presentase skor yang cukup baik. Namun berdasarkan hasil presentase skor yang di peroleh, jenis kelamin laki-laki, usia antara 19-26 tahun, latar belakang pendidikan Diploma, jabatan pengurus dan alumni yang berasal dari Provinsi Jawa Barat memiliki hasil presentase skor yang paling tinggi.

\section{Saran}

Saran disampaikan kepada pertama, pihak penyelenggara, sebaiknya dapat meningkatkan kualitas pelatihan serta dalam memilih calon peserta pelatihan sebaiknya yang siap untuk mengikuti pelatihan. Kedua, bagi pelatih agar memberikan materi secara optimal kepada peserta pelatihan sehingga penyerapanmateripesertadapatlebihbaiklagi. Ketiga, bagi peserta pelatihan agar mengikuti pelatihan dengan aturan yang telah dibuat oleh penyelenggara. Keempat, bagi peneliti selanjutnya akan lebih baik jika peneliti selanjutnya dapat lebih mempersiapkan desain penelitian dengan matang dengan menggunakan metode penelitian dan teknik pengumpulan data yang tepat sehingga hasil dari penelitian yang dilakukan oleh peneliti selanjutnya dapat berguna dan menjadikan tolak ukur dari lembaga yang diteliti oleh peneliti selanjutnya.

\section{Acuan Pustaka}

Departemen Pendidikan Nasional. 2004. Naskah Akademik Pendidikan Keluarga Berwawasan Gender (PKBG). Jakarta: Proyek Peningkatan Peran Masyarakat dan Pemampuan Kelembagaan Pengarusutamaan Gender.

Bambang Wahyudi. (2002). Manajemen Sumber Daya Manusia. Bandung : Sulita.

Bungin, Burhan. (2010). Metodologi Penelitian Kuantitatif: Komunikasi, Ekonomi, dan Kebijakan Publik 
Pedagogia : Jurnal IImu Pendidikan

Serta Ilmu-ilmu Sosial Lainnya. Peraturan Menteri Sosial No. 30 tahun Jakarta : Kencana Prenada Media 2011 tentang Standar Nasional Group. Pengasuhan Anak untuk Lembaga Kesejahteraan Sosial Anak

Darmawan, Deni. (2014). Metode Penelitian Kuantitatif. Bandung : PT Remaja Rosdakarya.

Menkokesra. (2013). Problematika Perlindungan Anak di Indonesia. Marzuki, Saleh. (2010). Pendidikan [Online]. Tersedia di http://nasyiah. Nonformal. Bandung : PT Remaja Rosdakarya. or.id/nasyiahpusat/?p=467 [8 Maret 2015].

Sarwono, W. Sarlito. 2009. Psikologi Sosial. Jakarta : Penerbit Salemba Humanika.

Sudjana, D. (2007). Sistem dan Manajemen Pelatihan Teori dan Aplikasi. Bandung: Falah Production.

Rachmawati, Ryna. (2008). Evaluasi Pendidikan dan Pelatihan (Diklat) Model Kirkpatrick. [Online]. Tersedia di http:// bdkjakarta.kemenag.go.id/index. php?a $=$ artikel\&id $=890$

Walgito, Bimo. (2010). Pengantar Umum September 2015].

Psikologi. Yogyakarta : Penerbit ANDI. 